Ermakov, P., \& Belousova, E. (2021). The relationship between the strategies of transferring the meanings of information messages and the meaning-of-life orientations of social networks users, International Journal of Cognitive Research in Science, Engineering and Education (IJCRSEE), 9(2), 279-289.

Original scientific paper

UDK:

\title{
The Relationship Between the Strategies of Transferring the Meanings of Information Messages and the Meaning-of-Life Orientations of Social
}

\section{Networks Users}

\author{
Pavel N. Ermakov (iD), Ekaterina Belousova² (iD) \\ ${ }^{1}$ Southern Federal University, Academy of Psychology and Pedagogy, Rostov-on-Don, Russian Federation, \\ e-mail: paver@sfedu.ru \\ ${ }^{2}$ Don State Technical University, Faculty of Psychology, Pedagogy and Defectology, Rostov-on-Don, Russian Federation, \\ e-mail: katy-belousova@mail.ru
}

\begin{abstract}
The aim of the work is to identify strategies for transferring the meanings of information messages used by students in social networks, and how these strategies are related to the students' meaning-of-life orientations. The study was conducted with the use of a theoretical method, as well as a survey, a content analysis, an expert method, a psychodiagnostic method, descriptive statistics, and also nonparametric tests, the Kruskal-Wallis H-test and Spearman's rank correlation method. Among modern youth, social networks are one of the most common sources of obtaining and distributing information. Therefore, it is important to find out what strategies for transferring the meanings of information messages are used by respondents. The expert method and content analysis allow us to identify 6 strategies for transferring meanings that students use in communication when transferring the meanings of various publications in social networks. Further analysis shows that each strategy has its own features of the meaning-of-life orientations components and significant relationships between the strategies of the meanings transferring and the components of the meaning-of-life orientations of social networks users are also revealed. Thus, we can conclude that the features of the transferring of meanings are significantly influenced by the meaning-of-life orientations, in particular, goals in life. Thus, the study emphasizes the importance of the semantic communication in social networks, the results of which can influence the effectiveness of communication, training, and the interaction among users.
\end{abstract}

Keywords: social networks, transferring of meanings, meaning-of-life orientations, the Internet.

\section{Introduction}

In modern psychology, there is a fairly extensive layer of research aimed at studying the various psychological problems of communication and the interaction among users in social networks.

As shown in the works (Haythomthwaite and Wellman, 1998; Butler, 2001), it is possible to divide social networks into informational and communicative: in informational ones there is an exchange of knowledge and the development of information, in communicative - the development of communication of participants. Although, it is possible to talk about the integration of social networks that perform an informational and communicative function. Fuhse (2009) identifies two levels in social networks: the first is represented by communication in the interaction processes, the second includes the meanings formed by participants in the social network.

A sufficient amount of research has been accumulated in psychology showing the positive and negative aspects of the dissemination of information in social networks. E. M. Rogers (Rogers, 2003) studied the spread of innovations and the influence of interpersonal relations on this process. M. Papagelis et al. (Papagelis, Bansal and Koudas, 2009) found that the dissemination of information among network participants increases their activity and affects the formation of their social significance. $\mathrm{M}$. S. Bezbogova studied the socio-psychological mechanisms of the formation of social attitudes in social networks and proved that the formation of social attitudes occurs through accentuated needs satisfied in social networks (Bezbogova and lonceva, 2016). I. S. Luchinkina revealed that the user's communicative behavior depends on the type of a cognitive distortion (Luchinkina, 2018). E. Klemenova, M. Ereshchenko "Corresponding author: katy-belousova@mail.ru 
Ermakov, P., \& Belousova, E. (2021). The relationship between the strategies of transferring the meanings of information messages and the meaning-of-life orientations of social networks users, International Journal of Cognitive Research in Science, Engineering and Education (IJCRSEE), 9(2), 279-289.

(Klemenova and Ereshchenko, 2020), studying the discourse of the social networks users, identified communicative strategies. At the same time, the authors argue that among the strategies, one can distinguish evaluation and forecasting strategies that have an impact on other users.

The problem of communication as one of the aspects involves the study of the transferring of the meanings of information messages in social networks.

In science, the issues of dynamics, transformation and transferring of meanings are raised and investigated. In the theory of communication V. E. Cronen (Cronen, 1995), the problem of the dynamics of meanings is considered, meaning is perceived as a phenomenon that is constantly changing in communication. A. Bard, J. Söderqvist, analyzing the features of communication in a network society, showed that in a network society, meanings are formed in the form of network messages. At the same time, they pay attention to the discrepancy between the transmitted meaning and the acquired meaning (Bard and Söderqvist, 2002).

Although the problem of transferring of meanings is relatively new in psychology, there are studies that reveal various aspects of transferring of meanings: in communication (Ivanova, 2014; Kibrik, 2018), in training (Abakumova et al., 2019; Suroedova, Tushnova and Belousova, 2020; Belousova, 2015), in professional activity (Hodgkinson and Sparrow, 2002), in advertising (Belousova and Stošić, 2019; Belousova, 2021; Miller and Allen, 2012).

The problem of transferring of meanings is most developed in the psychology of education. $E$. Y. Artemyeva together with I. B. Khanina showed the change of meanings in the educational process, their dynamics is associated with the assignment of transferred meanings (Artemyeva, 1999). I. V. Abakumova and L. C. Kagermazova, considering the teachers' activity through semantic communication, which is understood primarily as the transferring of meanings, distinguish various semantic techniques used by teachers (Abakumova and Kagermazova, 2008). In a comparative study of school teachers' educational techniques of different generations, Belousova revealed the peculiarities of the implementation of meaning transfer in the educational process of different generations of teachers (Belousova, 2015). B. Meskhi et al. (Meskhi, Ponomareva and Belousova, 2019) showed the representation of the transfer of meanings as a component of the pedagogical thinking of primary, secondary and high school teachers. A. K. Belousova and E. A. Suroedova (Belousova and Suroedova, 2010), studying the features of communication and the interaction of students in full-time and distance learning, identified various strategies of meaning transfer in students ' communication when solving professional problems. These strategies are considered by the authors through the ratio of verbal and non-verbal means of communication. E. Suroedova et al. (Suroedova, Tushnova and Belousova, 2020) considers the conditions for the development of abilities to convey meanings as a component of the development of communicative competencies.

Conducting a psychological analysis of management, G. P. Hodgkinson and P. R. Sparrow (Hodgkinson and Sparrow, 2002) present the features of strategic thinking, among which such semantic processes as the sense production and the sense transmission are distinguished. Meaning transfer is defined by them as the process of managers ' influence on the meanings that other people have.

In studies (Belousova and Stošić, 2019; Belousova, 2021), it was highlighted that students perceive advertising posters depending on the dominance of the system of life meanings. The authors conclude that the transferring of the meanings of advertisement takes place if the content of advertisement corresponds to the respondents' value-semantic features.

Miller F. M. and Allen C. T. (Miller and Allen, 2012), considering the technologies of the meaning transferring of a celebrity in advertising, showed that the transfer of meaning manifests itself as an update of the buyers 'belief system, causing them to change their attitude to the brand. At the same time, the authors confirmed in their study that, in accordance with the ideas of McCracken (McCracken, 2005), the mechanism of transmission of macro-meaning manifests itself at the micro level as a process working through indirect beliefs.

A. D. Husid (Husid, 2011) conducted a study of the peculiarities of the meanings perception of animated series by young people and found the existence of ethno-cultural differences, and also showed that the decoding of meanings is determined by the age and socio-psychological characteristics of the respondents.

It is possible to find a few works aimed at analyzing the features of the transferring of meanings in the Internet interaction. As a part of the information security study, P. N. Ermakov, I. V. Abakumova, A. $G$. Steinbuch emphasize the role of semantic technologies in information interaction, since they influence the transformation of the value-semantic sphere of social networks users (Ermakov, Abakumova and Stejnbuh, 2018).

In recent years, it has been shown that there are differences in the structure of value orientations of the generation Z students (Pishchik and Spivachuk, 2020), specific features of the value-semantic sphere 
Ermakov, P., \& Belousova, E. (2021). The relationship between the strategies of transferring the meanings of information messages and the meaning-of-life orientations of social networks users, International Journal of Cognitive Research in Science, Engineering and Education (IJCRSEE), 9(2), 279-289.

of the technical specialties students (Nikolenko, Zheldochenko and Lomova, 2020), with different attitudes to the past (Komerova et al., 2021), having differences in the sovereignty of the individual (Belousova et al., 2015) are highlighted. At the same time, there are classical works showing that the value-semantic sphere of a person in adolescence is structured, built up in a hierarchy. And personality is revealed in the ability to determine life goals, to realize the meaning and goals of one's own existence (Maslow, 1987; Rubinstein, 2002).

We believe that, on the one hand, the value-semantic sphere of young people, like any system at the stage of formation, is more susceptible to the external influence, as it is shown in the works (Maslow, 1987; Rubinstein, 2002). This is especially true for the situations where various ideas are well adapted and implemented in frequently repeated content that meets youth trends, which is confirmed in several works (Ermakov, Abakumova and Stejnbuh, 2018). On the other hand, since social networks users have the opportunity to be active creators of various kinds of content, the personal characteristics of young people are manifested through the information messages they broadcast. First of all, communication is influenced by the formed value and semantic features of the young person's personality, which relate to the highest structural levels of the regulatory system of an individual social behavior.

According to the views of A. Adler, the direction of a person's actions and motives is determined by the purpose of his life, and by understanding the purpose of life, it is possible to understand the hidden meaning of actions that are not really separate, but the parts of one whole (Adler, 2020).

In his works, Buhler reveals the problem of the meaning of life and believes that the presence of freedom of choice and life goals indicate the desire of the individual to materialize the meaning of life and it is a manifestation of freedom and inner activity of the individual. At the same time, life goals should be adequate to the nature of the individual and should lead to the realization of its capabilities and abilities (Buhler, 1964).

According to Frankl, meaning is the integrating factor of human life; the primary life force. The meaning is unique and specific for everyone (Frankl, 2006).

B. S. Bratus believes that the need to search for the meaning of life inherent in every human being, and satisfaction leads to the normal functioning of an individual (Bratus, 1988).

I. S. Kon as a plan for the establishment of the meaning of life calls integrity way of life - the need to "think of life not as a series of random, disconnected events, but as a holistic process that has a definite direction, continuity and content" (Kon, 1999).

In the works of D. A. Leontiev, the meaning of life is understood as "an energy characteristic of the semantic sphere, a quantitative measure of the degree and stability of the orientation of an individual's life activity to some meaning". What gives meaning to life can lie in the future (in the form of a goal), and be experienced in the present (a sense of fullness and saturation of life), and in the past (a sense of satisfaction with the results of a life lived) (Leontiev, 2019).

In our study, the task to investigate the relationship between the features of the meaning-oflife orientations and the strategies for transferring the meanings of social networks users' information messages is set.

There are various interpretations of the term strategy in psychology. In one of the influential psychological dictionaries, several meanings are indicated, depending on the subject field (Colman, 2001). The study examines the strategies of transferring of meanings, which are the components of a more general communicative strategy. In communication practice, T. A. Van Dijk considers a strategy rather as a plan of actions aimed at achieving various goals. At the same time, he finds a difference between the main (cognitive and semantic) and secondary strategies (Van Dijk, 2018).

In this case, focusing on the ideas of T. A. Van Dijk, we propose to consider semantic strategies (as a component of communication), the basis of which is the perception and transferring of the meanings of information messages. We assume that one of the criteria for identifying strategies for transferring the meanings of information messages in the respondents' comments in social networks is the initiation of new meanings in the commented message. In this case, it is possible to simulate the appearance of the following strategies for transferring the meanings of information messages. The received information is perceived by the respondent, fits into his value-semantic sphere, than included in the content of his knowledge in this subject area, causes activation of his attitude related to motives, goals, the meaning-oflife orientations, personality characteristics, which are expressed in the comments of these respondents. Therefore, the comments of the respondents in social networks reveal possible alternative strategies for the transferring of meanings, the classification of which is based on the actualization of new meanings in the strategy. In theoretical terms, the following strategies can be distinguished: sense-acceptance assimilation of the perceived meaning, as it is; meaning-formation - initiation of a new meaning based on the perceived information; sense-rejection - rejection and negative attitude to the perceived information; 
evaluation - the evaluation activity of respondents dominates in the comments, which marks the beginning of the initiation process that has not yet found verbal embodiment; empathy - the respondent is emotionally involved in the content of the perceived text; withdrawal - the respondent performs various actions that show an unwillingness to comment on messages.

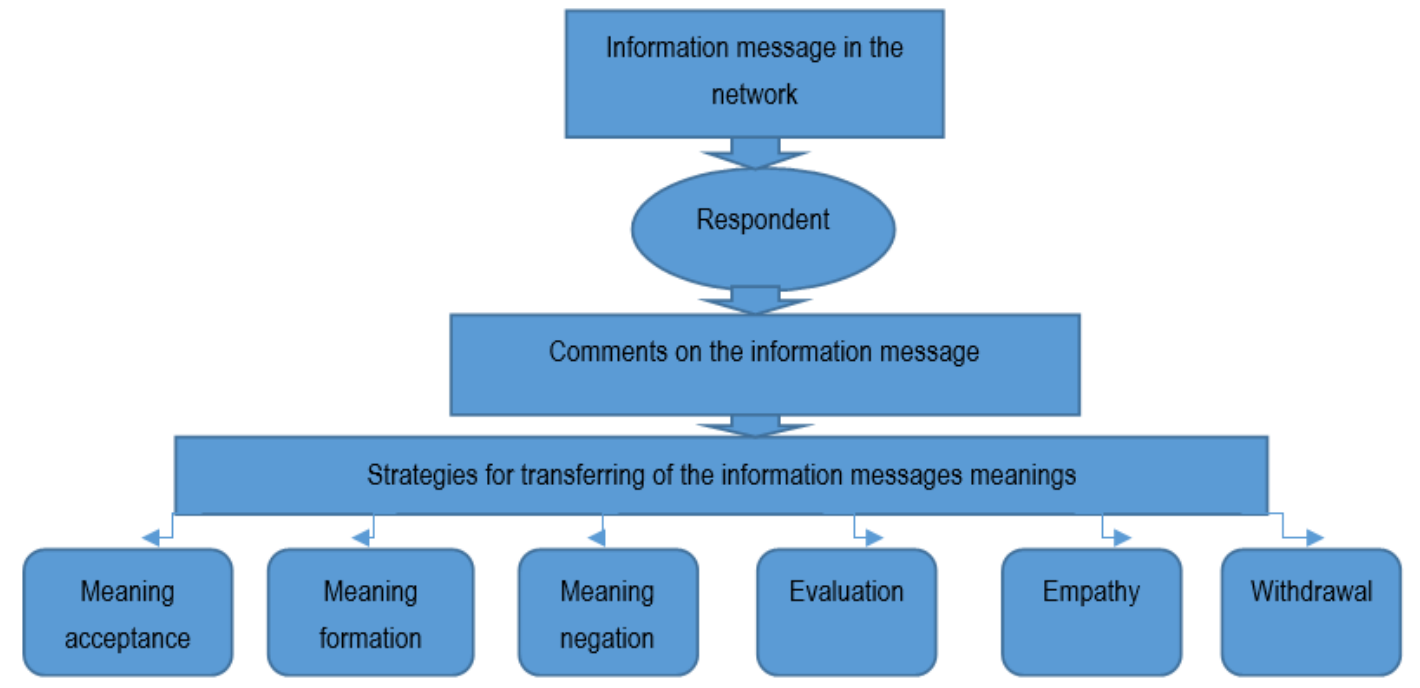

Figure 1. Model of strategies types for transferring of the information messages mening

The study is based on the following assumptions that: firstly, the VKontakte social network users who have different strategies for transferring of information messages meanings may differ in the severity of the components of the meaning-of-life orientations; secondly, there may be relationships typical to each strategy with the components of the meaning-of-life orientations.

\section{Materials and Methods}

The sample consists of 85 people - active users of social networks who are at the same time students of various specialties of the Don State Technical University (Rostov-on-Don). The age of the respondents differs from 18 to 24 years.

The author's questionnaire for diagnosing activity in social networks, the test "Meaning-of-life orientations" by D. A. Leontiev (Leontiev, 2000), the method of expert assessments, content analysis of a text are used in the study. The method of "Meaning-of-life orientations" consists of the following scales: The general indicator of the meaningfulness of life, Goals in life, the Process of life, the Effectiveness of life or the satisfaction with self-realization, the Locus of I-control, the Locus of life-control. This technique is aimed at diagnosing the features of the semantic sphere of a person associated with determining the localization of the meaning of life: in goals, in the process, as a result.

For the mathematical analysis of the results, the following methods are used: descriptive statistics, chi-square criterion, nonparametric Kruskal-Wallace criterion, Spearman's rank correlation method.

The study goes through the following stages:

1. Respondents were asked to answer the questionnaire questions concerning gender, age, preferred social networks and the time spent in them. Since the focus of the study did not involve the study of the Internet addicts, only the data of those users whose daily time in social networks did not exceed three hours are taken into account when processing the results.

2. The respondents completed the test "Meaning-of-life orientations" by D. A. Leontiev, and then they were presented with five publications on the social network "VKontakte" for review. Respondents were asked to choose several publications (posts) from them on any basis and leave their comments under them. The publications were selected in a non-random way: by means of the "SmmBoX" program, the most commented publications from various social network communities were selected within the last two months before the study, with the orientation that the number of likes and comments reflects the importance of the topic being raised for users.

3. Experts were invited to analyze the respondents ' comments. The group of experts consisted of five psychologists who owned the conceptual apparatus of the semantic sphere of the individual and who study the Internet in terms of psychology. The average age of experts is 40 years. The experts were 
Ermakov, P., \& Belousova, E. (2021). The relationship between the strategies of transferring the meanings of information messages and the meaning-of-life orientations of social networks users, International Journal of Cognitive Research in Science, Engineering and Education (IJCRSEE), 9(2), 279-289.

faced with the task of analyzing the respondents ' comments and using content analysis to determine their semantic content.

\section{Results}

A qualitative analysis of the comments made by a group of experts allowed us to identify six main strategies for the transferring of meanings in the presented sample: 1 . sense acceptance - the respondents accept the ideas transmitted in the publication; 2 . sense formation which is based on what they have read, the respondenta produce their own ideas and interpretations; 3 . evaluation - the respondents make an evaluative judgment regarding the publication; 4. empathy - the respondents express indifference, emotional involvement in the content of the publication; 5 . sense rejection - the respondents disagree with the content of the publication; 6 . withdrawal - the respondents demonstrate unwillingness to take part in the discussion.

The frequency analysis showed that the strategies for the transferring of meanings are distributed from most to least as follows: meaning formation (38.9\%), evaluation $(21.6 \%)$, withdrawal $(12.6 \%)$, sense rejection $(10.5 \%)$, sense acceptance $(9.5 \%)$, empathy $(6.8 \%)$. Statistics analysis of the differences in the frequency of distribution of the strategies for meanings transferring from publications was carried out by means of the chi-squared 2-criterion. The results obtained are presented in Table 1 and Table 2.

Table 1

Conjugacy table

\begin{tabular}{|c|c|c|c|c|c|c|c|c|}
\hline \multirow[b]{2}{*}{ Types of strategies } & & & \multicolumn{5}{|c|}{ Publication } & \multirow[b]{2}{*}{ Total } \\
\hline & & & 1 & 2 & 3 & 4 & 5 & \\
\hline \multirow{15}{*}{$\begin{array}{l}\text { The strategies of } \\
\text { transfering the meanings }\end{array}$} & \multirow{3}{*}{$\begin{array}{l}\text { Meaning } \\
\text { acceptance }\end{array}$} & Frequency & 2 & 8 & 4 & 1 & 3 & 18 \\
\hline & & $\begin{array}{l}\% \text { The strategies of transferring } \\
\text { the meanings }\end{array}$ & $11,1 \%$ & $44,4 \%$ & $22,2 \%$ & $5,6 \%$ & $16,7 \%$ & $100,0 \%$ \\
\hline & & $\%$ Publication & $6,1 \%$ & $14,0 \%$ & $9,5 \%$ & $3,8 \%$ & $9,4 \%$ & $9,5 \%$ \\
\hline & \multirow[t]{3}{*}{ Withdrawal } & Frequency & 5 & 8 & 3 & 3 & 5 & 24 \\
\hline & & $\begin{array}{l}\% \text { The strategies of transferring } \\
\text { the meanings }\end{array}$ & $20,8 \%$ & $33,3 \%$ & $12,5 \%$ & $12,5 \%$ & $20,8 \%$ & $100,0 \%$ \\
\hline & & $\%$ Publication & $15,2 \%$ & $14,0 \%$ & $7,1 \%$ & $11,5 \%$ & $15,6 \%$ & $12,6 \%$ \\
\hline & \multirow{2}{*}{$\begin{array}{l}\text { Meaning } \\
\text { formation }\end{array}$} & Frequency & 22 & 18 & 14 & 7 & 13 & 74 \\
\hline & & $\begin{array}{l}\% \text { The strategies of transferring } \\
\text { the meanings }\end{array}$ & $29,7 \%$ & $24,3 \%$ & $18,9 \%$ & $9,5 \%$ & $17,6 \%$ & $100,0 \%$ \\
\hline & \multirow{4}{*}{ Evaluation } & $\%$ Publication & $66,7 \%$ & $31,6 \%$ & $33,3 \%$ & $26,9 \%$ & $40,6 \%$ & $38,9 \%$ \\
\hline & & Frequency & 3 & 12 & 13 & 6 & 7 & 41 \\
\hline & & $\begin{array}{l}\% \text { The strategies of transferring } \\
\text { the meanings }\end{array}$ & $7,3 \%$ & $29,3 \%$ & $31,7 \%$ & $14,6 \%$ & $17,1 \%$ & $100,0 \%$ \\
\hline & & $\%$ Publication & $9,1 \%$ & $21,1 \%$ & $31,0 \%$ & $23,1 \%$ & $21,9 \%$ & $21,6 \%$ \\
\hline & \multirow[t]{3}{*}{ Empathy } & Frequency & 1 & 1 & 1 & 8 & 2 & 13 \\
\hline & & $\begin{array}{l}\% \text { The strategies of transferring } \\
\text { the meanings }\end{array}$ & $7,7 \%$ & $7,7 \%$ & $7,7 \%$ & $61,5 \%$ & $15,4 \%$ & $100,0 \%$ \\
\hline & & $\%$ Publication & $3,0 \%$ & $1,8 \%$ & $2,4 \%$ & $30,8 \%$ & $6,3 \%$ & $6,8 \%$ \\
\hline \multirow{6}{*}{ Total } & \multirow{6}{*}{$\begin{array}{l}\text { Meaning } \\
\text { negation }\end{array}$} & Frequency & 0 & 10 & 7 & 1 & 2 & 20 \\
\hline & & $\begin{array}{l}\% \text { The strategies of transferring } \\
\text { the meanings }\end{array}$ & $0,0 \%$ & $50,0 \%$ & $35,0 \%$ & $5,0 \%$ & $10,0 \%$ & $100,0 \%$ \\
\hline & & $\%$ Publication & $0,0 \%$ & $17,5 \%$ & $16,7 \%$ & $3,8 \%$ & $6,3 \%$ & $10,5 \%$ \\
\hline & & Frequency & 33 & 57 & 42 & 26 & 32 & 190 \\
\hline & & $\begin{array}{l}\% \text { The strategies of transferring } \\
\text { the meanings }\end{array}$ & $17,4 \%$ & $30,0 \%$ & $22,1 \%$ & $13,7 \%$ & $16,8 \%$ & $100,0 \%$ \\
\hline & & $\%$ Publication & $100,0 \%$ & $100,0 \%$ & $100,0 \%$ & $100,0 \%$ & $100,0 \%$ & $100,0 \%$ \\
\hline
\end{tabular}


Ermakov, P., \& Belousova, E. (2021). The relationship between the strategies of transferring the meanings of information messages and the meaning-of-life orientations of social networks users, International Journal of Cognitive Research in Science, Engineering and Education (IJCRSEE), 9(2), 279-289.

Table 2

X2 Criteria

\begin{tabular}{|c|c|c|c|}
\hline & $\begin{array}{l}\text { The } \\
\text { value }\end{array}$ & df & Asymptote. significance (2-sided) \\
\hline Pearson's chi-squared test & $51,952^{\mathrm{a}}$ & 20 &, 000 \\
\hline likelihood ratio & 46,393 & 20 &, 001 \\
\hline Linear-linear connection & 1,624 & 1 & ,203 \\
\hline Number of valid observations & 190 & & \\
\hline
\end{tabular}

According to the results obtained, the strategies for the transferring of meanings differ significantly in publications with various orientations $\left(X^{2}=51.952 ; p=0.000\right)$.

The next task was to find the answer to the question how the system of meaning-of-life orientations differs among young social networks users who apply different strategies for the meanings transferring.

For this purpose, an analysis was carried out with the use of the Kraskel-Wallis H-test (Table 3), which showed the presence of significant differences in the following components of the respondents meaning-of-life orientations: Goals in life, Locus of life control, Meaningfulness of life; as well as the presence of a tendency to significant differences in the following components: the Process of life, the Result of life.

\section{Table 3}

The average values of indicators of life-meaning orientations in Respondents with different strategies for transferring the meanings of information messages

\begin{tabular}{cccccc}
\hline $\begin{array}{c}\text { Strategies for transferring } \\
\text { meanings/Life-meaning } \\
\text { orientations. }\end{array}$ & Goals in life & $\begin{array}{c}\text { Locus - control } \\
\text { of life }\end{array}$ & $\begin{array}{c}\text { The meaningfulness of } \\
\text { life }\end{array}$ & $\begin{array}{c}\text { The process of } \\
\text { life }\end{array}$ & $\begin{array}{c}\text { The result of } \\
\text { life }\end{array}$ \\
\hline $\begin{array}{c}\text { Sense acceptance } \\
\text { Withdrawal }\end{array}$ & 32,5556 & 31,6667 & 105,7222 & 29,6667 & 25,9444 \\
Meaning formation & 31,0417 & 31,6667 & 103,0417 & 31,3333 & 26,25 \\
Evaluation & 27,6892 & 28,1892 & 92,1892 & 26,5946 & 23,1351 \\
Empathy & 32,6341 & 29,8049 & 102,634 & 29,1707 & 25,9756 \\
\hline Kruskal-Wallis H test & 26,7692 & 25,1538 & 76,4615 & 26,6154 & 21,8462 \\
df & 29,2 & 29,6 & 94,45 & 26 & 23,95 \\
p & 16,576 & 14,859 & 14,521 & 11,256 & 11,031 \\
\hline
\end{tabular}

The next step of our research was to study the relationships between various strategies for transferring of the information messages meanings and the components of the meaning-of-life orientations (Table 4).

Table 4

The relationship between the strategies of the meanings transferring and the respondents' meaningof-life orientations

\begin{tabular}{|c|c|c|c|c|c|}
\hline $\begin{array}{l}\text { The strategies of the meanings transferring / } \\
\text { Meaning-of-life orientations }\end{array}$ & Meaning acceptance & Withdrawal & Meaning formation & Evaluation & Empathy \\
\hline \multirow{2}{*}{ Goals in life } & & & ,197** &,$- 194^{\star \star}$ & \\
\hline & & &, 006 & 007 & \\
\hline \multirow{2}{*}{ The process of life } & &,$- 164^{*}$ & & & \\
\hline & &, 024 & & & \\
\hline \multirow{2}{*}{ The result of life } & & &, $154^{*}$ & & \\
\hline & & & 034 & & \\
\hline \multirow{2}{*}{ Locus of I-control } &,$- 146^{*}$ & &, $151^{*}$ & & \\
\hline &, 044 & & 037 & & \\
\hline \multirow{2}{*}{ Locus - control of life } & &,$- 161^{\star}$ & & &, $171^{\star}$ \\
\hline & &, 026 & & & ,018 \\
\hline \multirow{2}{*}{ Meaningfulness of life } &,$- 148^{*}$ & & & &, $160^{*}$ \\
\hline &, 042 & & & &, 028 \\
\hline
\end{tabular}


Ermakov, P., \& Belousova, E. (2021). The relationship between the strategies of transferring the meanings of information messages and the meaning-of-life orientations of social networks users, International Journal of Cognitive Research in Science, Engineering and Education (IJCRSEE), 9(2), 279-289.

As the correlation analysis showed, the lower the indicators of the "I" locus of control ( $r s=-0,146$; $p=0.044$ ) and the meaningfulness of life ( $r s=-0,148 ; p=0.044)$, the more likely the respondents are to choose a sense-acceptance strategy. This strategy is typical for students who have a rather low level of meaningfulness of life, and a semantic choice, the perception of themselves as the master of life are not characteristic for them.

The lower the indicator of the life process ( $r s=-0.164 ; p=0.024$ ) and the locus of life control ( $r s=$ $-0.161 ; p=0.026)$, the higher the probability of respondents to choose the withdrawal strategy. Thus, the withdrawal strategy is rather typical to those students who do not show satisfaction with life and do not feel like its masters.

With an increase in the values of the indicators of goals in life ( $r s=0.197 ; p=0.006)$, the process of life ( $r s=0.140 ; p=0.054$ ), the result of life ( $r s=0.154 ; p=0.034$ ), the "l" locus of control of ( $r s=0.151$; $p=0.037$ ) and the meaningfulness of life ( $r s=0.141 ; p=0.053$ ), the probability of using a meaning-forming strategy by respondents increases. The results obtained indicate that students with this strategy focus on plans-building, strive for self-realization, they are interested in life itself, they are satisfied with its results, considering themselves as the masters of their life, their life is characterized by meaningfulness.

The probability that the respondents choose an assessment strategy is higher, if the indicator of goals in life are lower ( $r s=-0,194 ; p=0.007$ ). The assessment strategy is observed among students who are not distinguished by purpose-fulness and the desire to form goals for the future.

The empathy strategy is more likely to be chosen if the indicators of the locus of life control (rs= $0.171 ; p=0.018$ ) and the meaningfulness of life are higher ( $r s=0.160 ; p=0.028)$. This strategy characterizes students who have a belief in the ability to manage their lives, a high level of general meaningfulness of life.

There were no significant connections with the meaning-negation strategy.

\section{Discussions}

The conducted research showed the presence of various strategies for the transferring of information messages meanings, which were found among the respondents of the "VKontakte" social network.

The obtained data shows the dominance of the meaning formation strategy, which clearly prevails over all the other strategies (38.8\%). It seems that this situation reflects the individual nature of the respondents, due to the fact that each person interprets the received messages, forms new meanings of the received messages. The strategy of meaning formation is confirmed in the works of other authors, who mainly concentrate their research activity on the identification of various types and types of meaning formation. Abakumova et al., (Abakumova et al., 2018) defines two strategies of meaning formation: developmental and adaptive. S. V. Gurov (Gurov, 2012) proposed strategies of meaning formation of students related to the peculiarities of their professional orientation: self-attitude, attitudes to life and profession, communication. A. B. Savchenko (Savchenko, 2012) identifies communicative strategies of teachers: manipulative and conventional, which are based on different ways teachers transfer their meanings.

The second place in the representation of strategies is occupied by the "Evaluation" strategy $(21.6 \%)$. It seems that the dominance of this strategy corresponds to the general characteristic of the human psyche, which integrates the reflection of the world and the attitude to it (Rubinstein, 2002). From the point of view (Belousova, 2010), the meanings formed by a person are presented in the form of assessments, but have not yet been verbalized by a person. Therefore, it can be assumed that the respondents have new meanings in the comments which are in the form of ratings, which young people have not yet been able to reflect and express in verbal form. It can be assumed that these meanings can exist in a non-verbalized form, as in the situation of an ordinary direct interaction face to face. Similar studies already exist. Thus, in a study (Holtgraves and Robinson, 2020), it was found that in the conditions of the digital interaction, emoticons make it easier to understand the meaning.

The "withdrawal" strategy $(12.6 \%)$ is the third most pronounced and can mean informational behavior aimed at not accepting information. It seems to us that the reasons for this behavior and this strategy of meanings transferring can be very diverse. As shown in the work (Ermakov, Abakumova and Osipova, 2016), in the educational environment, when students are faced with a contradictory, frustrating situation, they may have semantic barriers, in response to which students can "walk away" from solving problems and contradictions. In studies of a potentially problematic situation of interpersonal thinking (Belousova and Vyshkvyrkina, 2015), the following strategies of "avoiding" the solution of a contradiction were identified: according to the criterion of activity - "active" and "passive"; according to the criterion 
Ermakov, P., \& Belousova, E. (2021). The relationship between the strategies of transferring the meanings of information messages and the meaning-of-life orientations of social networks users, International Journal of Cognitive Research in Science, Engineering and Education (IJCRSEE), 9(2), 279-289.

of acceptance of the situation -"denial" and "acceptance"; according to the criterion of orientation "aggressive" (focus on another) and "mercantile" (focus on oneself).

Lower figures were obtained for the "Sense-negation" strategy (10.5\%). Meaning-denial means that a person denies the meaning extracted from the text of an information message. He actively rejects it, which, in our opinion, indicates the potential for the formation of new meanings. Similar values were obtained for the "Sense Acceptance" strategy (9.5\%), which means that the respondent assimilates the meaning of the message transmitted and embedded in the information.

The lowest values fall on the strategy - "Empathy" (6.8\%), which emphasizes the emotional acceptance of information. One can even assume that in this case there is a certain version of the acceptance of meaning, which, however, exists in an emotional form, in the form of empathy and empathy for the context of an information message. And in this case, the situation also manifests itself when the respondents have not been able yet to reflect and express their meanings. In the study (Belousova and Belousova, 2020), the dominance of altruistic and communicative emotional experiences was found in psychology students when solving mental problems. Empathy can also be attributed to the sphere of communicative and altruistic experiences, and then it becomes clear that the dominance of the strategy of meanings transferring based on empathy as a manifestation of one of the dominant emotional states typical to psychologists. These results are also consistent with studies (Nerdrum, 1997), which showed a fairly high level of empathy among students of the Faculty of Social Work.

The strategies of meaning transferring highlighted in our study are in some respects consistent with the list of communicative strategies presented by various authors: for example, the "Evaluation" strategy existing in our classification is highlighted in the work (Klemenova and Ereshchenko, 2020). P. B. Floreddu and F. Cabiddu (Floreddu and Cabiddu, 2016) identified communicative strategies for brand promotion - egocentric, conversational, selective, openness, secret and supportive. Although the authors do not address the issues of the transferring of meanings, but in general they point at the development of information in social networks through the use of various psychological methods of influencing the audience. The work (Martin and MacDonald, 2020) emphasizes the role and importance of the means of personal, private, interpersonal communication, including stories, selfies, various personal photos and comments for the intensification of scientific communication. However, existing studies do not yet reflect the specifics of the presentation and formation of the meanings of messages in social networks.

The analysis of the severity and interrelation of various components of meaning-of-life orientations with strategies for the transferring of meanings (according to Table 3 and Table 4) allows us to assert that users who use assessment and sense-acceptance strategies see their Goals in life and plan their future best, then users with strategies of withdrawal, sense-denial, sense-formation, and users with an empathy strategy who are more inclined to live today or yesterday.

The values of the "Locus of life-control" scale indicate that users with strategies of meaning acceptance and withdrawal most rely on their ability to control their lives. They followed by users using strategies of evaluation, meaning-denial, meaning-making and empathy, who tend to see the hand of fate in what is happening and are convinced that life is beyond their control.

The general indicator of the meaningfulness of life is characterized by the following distribution of user groups: the highest indicator of the meaningfulness of life is recorded among users with prevailing strategies of sense acceptance, withdrawal, evaluation; the level of meaningfulness of life is lower among users who apply strategies of sense denial, sense formation, empathy.

In accordance with the indicators on the "Process of Life" scale, users who apply strategies of withdrawal and sense acceptance see their life as rich and interesting, users with strategies of assessment, empathy, sense formation and sense negation represent their life somewhat less bright.

The values on the "Result of life" scale indicate that the satisfaction of the life of users using various strategies for transferring meanings is felt by them as follows: users with the strategies of withdrawal, evaluation, sense acceptance evaluate the productivity of the lived life segment above all; users with the strategies of sense denial, sense formation and empathy evaluate the effectiveness of their life less positively.

The results obtained are consistent with studies of the human semantic sphere (Komerova et al., 2021) and strategies of meaning formation (Godunov et al., 2017; Gurov, 2012; Zorina and Zelenov, 2016; Savchenko, 2012), in which the expression of components of life-meaning orientations was found in the implementation of various strategies of meaning formation. In particular, the existence of interrelations between the indicators of the goal in life and the strategy of meaning formation by students was shown in the work (Gurov, 2012). In the work (Godunov et al., 2017), it was revealed that one of the main markers of the strategy of meaning formation is the indicator of the meaningfulness of life. E. V. Zorina showed that high values of indicators: the meaningfulness of life, the locus of I-control, the locus of life-control, goals 
Ermakov, P., \& Belousova, E. (2021). The relationship between the strategies of transferring the meanings of information messages and the meaning-of-life orientations of social networks users, International Journal of Cognitive Research in Science, Engineering and Education (IJCRSEE), 9(2), 279-289.

in life are characteristic of teachers who seek to use semantic techniques in pedagogical activity (Zorina and Zelenov, 2016).

\section{Conclusions}

Thus, on the basis of the conducted research, some generalizations can be formulated. First of all, we can say that social network users have identified strategies for the transferring of meanings when commenting on information messages: meaning acceptance, meaning formation, evaluation, empathy, meaning denial, withdrawal. The selection was based on the criterion - the initiation of new meanings in the commented message. According to the frequency of use, the strategies were distributed in the following sequence: meaning formation, evaluation, withdrawal, meaning rejection, meaning acceptance, empathy. Thus, the most pronounced is the strategy of meaning formation, the least pronounced is the strategy of empathy.

The highlighted strategies for the meaning transferring are shown by a variety of possible behavioral, in this case, verbal patterns demonstrated by respondents in communication in social networks. We believe that the selected strategies make up a combination typical to every person, but the actualization of a specific strategy can be determined by various predictors associated with the communicative situation, with the content of information, its significance for a person, as well as a range of personal, value, semantic, cognitive and other possible psychological determinants that require separate research.

The study identified the relationships that exist between the components of life-meaning orientations and the strategies for the transferring of meanings. It was shown that the greatest number of connections exists between the strategy of meaning formation and the components of the Goal of life, the Result of Life, the Locus of I-control. Two interrelations were revealed between the strategies: withdrawal, senseacceptance, empathy - and other components of life-meaning orientations: the process of life, the Locus of Life-control, the Meaningfulness of life. The evaluation strategy has one relationship with the Purpose of life, meaning-negation has no relationships. Thus, in our opinion, the study shows that there are close relationships between the semantic sphere of the respondents and the strategies for the transferring of meanings that they implement in comments. It seems that this direction requires further research expanding the range of semantic and value characteristics of the respondents.

\section{Acknowledgements}

The authors are grateful to all participants of the research.

\section{Conflict of interests}

The authors declare no conflict of interest.

\section{References}

Abakumova I. V., Ermakov P. N., \& Godunov M. V. (2018). Polar Meaning-Building strategies: Acmeological Characteristics. Psychology in Russia: State of the Art, 11(4), 200-210. https://doi.org/10.11621/pir.2018.0413

Abakumova, I., Bakaeva, I., Grishina, A., \& Dyakova, E. (2019). Active Learning Technologies in Distance Education of Gifted Students. International Journal of Cognitive Research in Science, Engineering and Education (IJCRSEE), 7(1), 85-94. https://doi.org/10.5937/ijcrsee1901085A

Abakumova, I. V., \& Kagermazova, L. C. (2008). Tekhnologii napravlennoj translyacii smyslov v obuchenii [Technologies of task-oriented sense translation in education]. Rossijskij psihologicheskij zhurnal, 4, 56-64. Retrieved from https:// cyberleninka.ru/article/n/tehnologii-napravlennoy-translyatsii-smyslov-v-obuchenii

Adler, A. (2020). The science of living. General Press. Retrieved June 23, 2021 from https://books.google.ru/books/about/ The_Science_of_Living.html?id=TOjcDwAAQBAJ\&redir_esc=y

Artem'eva, E. YU. (1999). Osnovy psihologii sub"ektivnoj semantiki [Fundamentals of the psychology of subjective semantics]. M.: Nauka: Smysl. Retrieved from https://klex.ru/djr

Bard, A., \& Söderqvist, J. (2002). The New Power Elite and Life After Capitalism. Pearson Education. Retrieved from https:/l books.google.ru/books?id=1GjK73ifXblC\&redir_esc=y

Belousova, A. K., \& Suroedova, E. A. (2010). Strategii smysloperedachi studentov v processah obshcheniya [Strategies of students' meanings transfer in communication processes]. Izvestiya YUzhnogo federal'nogo universiteta. Pedagogicheskie nauki, 10, 111-120. Retrieved from https://elibrary.ru/item.asp?id=15269792

Belousova, A. K. (2010). Samoorganizaciya sovmestnoj myslitel'noj deyatel'nosti: sistemnyj podhod [Self-organization of joint mental activity: a systematic approach]. Saarbrücken: LAP LAMBERT. Retrieved from https://www.elibrary.ru/item. asp?id=27814349

Belousova, A. K., , \&Vyshkvyrkina, M. A. (2015). Osobennosti myshleniya o drugom cheloveke v yunosheskom vozraste 
Ermakov, P., \& Belousova, E. (2021). The relationship between the strategies of transferring the meanings of information messages and the meaning-of-life orientations of social networks users, International Journal of Cognitive Research in Science, Engineering and Education (IJCRSEE), 9(2), 279-289.

[Features of thinking about another person in youth]. In Ryumshina, L.I \& Ermakov, P.N. (Eds), Prikladnaya psihologiya ob-shcheniya i mezhlichnostnogo poznaniya [Applied Psychology of Communication and Interpersonal Cognition]. (Pp. 46-56). Moskva, Rossiya: Kredo https://www.elibrary.ru/item.asp?id=25135407

Belousova, A. K. (2015). Osobennosti smysloperedachi pedagogov v processe obucheniya [Especially the sense of meaningmaking of teachers in the learning process]. Psihologiya obucheniya, 9, 4-14. Retrieved from https://elibrary.ru/item. asp?id=24037951

Belousova, A. K., Barsukova, O. V.., Tushnova, Y. A., Vyshkvyrkina, M. A., Krischenko, E. P, Mozgovaya, N. N., et al. (2015). The scope of Values and Limits of the Personal Psychological Space of Students-Emigrants. Mediterranean Journal of Social Sciences, 6(4 S4), pp. 238-241.https://doi.org/10.5901/mjss.2015.v6n4s3p379

Belousova, A. K., Vyshkvyrkina, M. A. (2015). Osobennosti myshleniya o drugom cheloveke v yunosheskom vozraste [Features of thinking about another person in youth]. In Ryumshina, L.I \& Ermakov, P. N. (Eds), Prikladnaya psihologiya obshcheniya i mezhlichnostnogo poznaniya (Pp. 46-56). Moskva, Rossiya: Kredo Retrieved from https://www.elibrary. ru/item.asp?id=25135407

Belousova E., \& Stošić L. (2019). Perception and translation of advertising meanings: students ' attitudes. SHS Web of Conferences. Trends in the Development of Psycho-Pedagogical Education in the Conditions of Transitional Society (ICTDPP-2019), 70, 08007. https://doi.org/10.1051/shsconf/20197008007

Belousova, A., \& Belousova, E. (2020). Gnostic emotions of students in solving of thinking tasks. International Journal of Cognitive Research in Science, Engineering and Education, 8(2), 27-34. https://doi.org/10.5937/IJCRSEE2002027B

Belousova, E. E. (2021). Ustanovki studentov pri vospriyatii transliruemyh smyslov reklamy [Students' attitudes in the perception of broadcast advertising meanings]. Vestnik Samarskogo gosudarstvennogo tekhnicheskogo universiteta. Seriya: Psihologo-pedagogicheskie nauki. 18(1), 5-16. https://doi.org/10.17673/vsgtu-pps.2021.1.1

Bezbogova, M. S., \& lonceva, M. V. (2016). Social'no-psihologicheskij portret sovremennoj molodezhi [Socio-psychological aspects of user interaction in virtual social networks]. Internet zhurnal «Mir nauki», 4(6), 35. Retrieved from http://mirnauki.com/PDF/35PSMN616.pdf

Bratus', B. S. (1988). Anomalii lichnosti [Personality anomalies]. M.: Mysl'. Retrieved from http://medbookaide.ru/books/ fold1002/book1221/p1.php

Buhler, C. (1964). The Human Course of Life in its Goal Aspects. Journal of Humanistic Psychology, 4(1), 1-18. https://doi. org/10.1177/002216786400400101

Butler, V. S. (2001). Membership Size, Communication Activity, And Sustainability: A Resource-based Model of Online Social Structures. Information Systems Research, 12(4). https://doi.org/10.1287/isre.12.4.346.9703

Colman, A. (2001). A dictionary of psychology. Oxford, New York: Oxford University Press. Retrieved from https://archive.org/ details/dictionaryofpsyc00colm

Cronen, V. E. (1995). Practical Theory and the Tasks Ahead for Social Approaches to Communication. In W. Leeds-Hurwitz (Ed.), Social approaches to communication (Pp. 217-242). NY: Guilford. https://doi.org/10.3886/E117002V2.

Ermakov, P. N., Abakumova, I. V, Stejnbuh A. G. (2018). Tekhnologii ocenki effektivnosti vozdejstviya internet-kontentov antiterroristicheskoj napravlennosti na ideologicheskie ustanovki molodezhi. In Profilaktika ekstremizma i terroristicheskogo povedeniya molodezhi $v$ internet-prostranstve: tradicionnye $i$ innovacionnye formy. M: Kredo. Retrieved from https://www.elibrary.ru/item.asp?id=37239027\&pff=1

Ermakov, P. N., Abakumova, I. V., \& Osipova A. A. (2016). Smyslovye bar'ery v obuchenii: didakticheskoe soderzhanie i tekhnologii preodoleniya [Semantic barriers in learning: didactic content and overcoming technologies] [Monograph]. M.: KREDO, 274 s. Retrieved from https://elibrary.ru/download/elibrary_27361398_35869729.pdf

Ermakov, P. N., Abakumova, I. V, SHtejnbuh A. G. (2018). Tekhnologii ocenki effektivnosti vozdejstviya internet-kontentov antiterroristicheskoj napravlennosti na ideologicheskie ustanovki molodezhi [Technologies for evaluating the effectiveness of the impact of anti-terrorist Internet content on the ideological attitudes of young people]. In Profilaktika ekstremizma i terroristich-eskogo povedeniya molodezhi v internet-prostranstve: tradicionnye i innovacionnye formy. [Prevention of extremism and terrorist behavior of youth in the Internet space: traditional and innovative forms]. M: Kredo. https://www.elibrary.ru/item.asp?id=37239027\&pff=1

Floreddu, P. B., \& Cabiddu, F. (2016). Social media communication strategies. Journal of Services Marketing, 30(5), 490-503. https://doi.org/10.1108/JSM-01-2015-0036

Frankl, V. E. (2006). Man's Search for Meaning. Beacon Press. Retrieved June 27, 2021, Retrieved from https://www. strandbooks.com/product/9780807014271?title=mans search for meaning

Fuhse, J. A. (2009). The Meaning Structure of Social Networks. Sociological Theory 27(1), 51-73. https://doi.org/10.1111/ j.1467-9558.2009.00338.x

Godunov, M. V., Elagina M. YU., \& Belova E. V. (2017). Issledovanie lichnostnyh profilej polyarnyh strategij smysloobrazovaniya [Studying the personal profiles of the polar meaning-making strategies]. Rossijskij psihologicheskij zhurnal, 14(3), 3047. https://doi.org/10.21702/rpj.2017.3.2

Gurov. S. V. (2012). Psihologicheskie osobennosti smysloobrazovaniya studentov: tipy, stili, strategii. Rossijskij psihologicheskij zhurnal, 1, 62-67. https://doi.org/10.21702/rpj.2012.1.6

Haythomthwaite, C., \& Wellman, B. (1998). Work, Friendship, And Media Use for Information Exchange in a Networked Organization. Journal of the American Society for Information Science, 49(12), 1101-1114. https://doi.org/10.1002/ (SICI)1097-4571(1998)49:12<1101::AID-ASI6>3.0.CO;2-Z

Hodgkinson, G. P., \& Sparrow, P. R. (2002). The Competent Organization: A Psychological Analysis of the Strategic Management Process. Maidenhead: Open University Press, 27(1),154-157. https://doi.org/10.2189/asqu.51.3.502

Holtgraves, T., \& Robinson, C. (2020). Emoji can facilitate recognition of conveyed indirect meaning. PLoS ONE 15(4), e0232361. https://doi.org/10.1371/journal.pone.0232361

Husid, A. D. (2011). Problema social'no-psihologicheskih i vozrastnyh osobennostej vospriyatiya podrostkami i molodezh'yu mul'tserialov parodijnogo soderzhaniya [The problem of socio-psychological and age-related features of the perception of parody animated series by adolescents and young people]. Kul'turno-istoricheskaya psihologiya, 7(2), 94-97. https:// psyjournals.ru/kip/2011/n2/44491_full.shtml

Ivanova, O. E. (2014). Bytie smysla $v$ kommunikacii: genezis problemy smysla $v$ kommunikacii [Being of meaning in 
Ermakov, P., \& Belousova, E. (2021). The relationship between the strategies of transferring the meanings of information messages and the meaning-of-life orientations of social networks users, International Journal of Cognitive Research in Science, Engineering and Education (IJCRSEE), 9(2), 279-289.

communication: the genesis of the problem of meaning in communication]. Cennosti i smysly, 4(32), 58-65. https:// cyberleninka.ru/article/n/bytie-smysla-v-kommunikatsii-genezis-problemy-smysla-v-kommunikatsii

Kibrik, A. A. (2018). Russkij mul'tikanal'nyj diskurs. CHast' I. Postanovka problemy [Russian multichannel discourse. part I. setting up the problem]. Psihologicheskij zhurnal, 39(1), 70-80. https://doi.org/10.7868/S0205959218010075

Klemenova, E., \& Ereshchenko, M. (2020). Communicative Strategies of Social Media Discourse. E3S Web of Conferences. Innovative Technologies in Science and Education, ITSE-2020, 210, 16001. https://doi.org/10.1051/ e3sconf/202021016001

Komerova, N., Zvezdina, G., Elagina, M., \& Nemchenko, E. (2021). Characteristic Features of the Value-Semantic Sphere of Students with Various Attitudes to Past Experience. E3S Web of Conferences. Ural Environmental Science Forum on Sustainable Development of Industrial Region, UESF 2021, 25820, 070652021.Retrieved from https://www.e3sconferences.org/articles/e3sconf/abs/2021/34/contents/contents.html

Kon, I. S. (1999). Sociologicheskaya psihologiya. Moscow: Moskovskij psihologo-social'nyj institut; Voronezh: Izdatel'stvo NPO «MODEK». Retrieved from https://iearas.ru/index.php?go=Files\&in=view\&id=160

Leont'ev, D. A. (2019). Psihologiya smysla: priroda, stroenie i dinamika smyslovoj real'nosti [Psychology of meaning: the nature, structure and dynamics of semantic reality]. M.: Smysl. Retrieved June 25, 2021 https://mybook.ru/author/d-aleontev/psihologiya-smysla-priroda-stroenie-i-dinamika-smy/read/

Leont'ev, D. A. (2000). Test smyslozhiznennyh orientacii (SZHO). Moscow: Smysl. Rerieved from http://publishing.smysl.ru/ book/sgo/ManSGO.pdf

Luchinkina, I. S. (2018). Kognitivnye mekhanizmy kommunikativnogo povedeniya v internet-prostranstve [Cognitive mechanisms of communicative behavior in the internet space]. Nauchnyj rezul'tat. Pedagogika i psihologiya obrazovaniya, 4(3), 56-70. Retrieved from http://rrpharmacology.ru/media/pedagogy/2018/3/\%D0\%9B\%D1\%83\%D1\%87\%D0\%B8\%D0\% BD\%D0\%BA\%D0\%B8\%D0\%BD\%D0\%BO.pdf

Martin, C, \& MacDonald, B. H. (2020). Using interpersonal communication strategies to encourage science conversations on social media. PLOS ONE 15(11), e0241972. https://doi.org/10.1371/journal.pone.0241972

Maslow, A. (1987). Motivation and Personality. New York: Addison-Wesley Educational Publishers Inc. Retrieved from https:// www.amazon.com/Motivation-Personality-3rd-Abraham-Maslow/dp/0060419873

McCracken, G. (2005). Culture and consumption II: Markets, meaning and brand management. Bloomington. Bloomington, Indiana: Indiana University Press. Retrieved from https://iupress.org/9780253217615/culture-and-consumption-ii/

Meskhi, B., Ponomareva, S., Belousova, A. (2019). Collaborative Learning: How Teachers Use Thinking in Educational Practice. In Proceedings of the $2^{\text {nd }}$ International Conference on Education, Science and Social Development. Changsha, China. https://doi.org/10.2991/essd-19.2019.1

Miller, F. M., Allen, C. T. (2012). How does celebrity meaning transfer? Investigating the process of meaning transfer with celebrity affiliates and mature brands. Journal of Consumer Psychology, 22, 443-452. https://doi.org/10.1016/j. jcps.2011.11.001

Nerdrum, P. (1997). Maintenance of the Effect of Training in Communication Skills: A Controlled Follow-Up Study of Level of Communicated Empathy. British Journal of Social Work, 27(5), 705-722. Retrieved from https://www.academia. edu/25702591/Maintenance_of_the_Effect_of_Training_in_Communication_Skills_A_Controlled_Follow_Up_Study_ of_Level_of_Communicated_Empathy

Nikolenko. O., Zheldochenko, L. \& Lomova N. (2020). Psychological and Pedagogical Conditions for the Formation of ValueSemantic Sphere of Students of Technical Specialties. E3S Web of Conferences 175, 15029. https://doi.org/10.1051/ e3sconf/202017515029

Papagelis, M., Bansal, N., Koudas, N. (2009). Information Cascades in the Blogosphere: A Look Behind the Curtain. ICWSM, 2009. In Proceedings of the Third international AAAl conference on weblogs and social media. California, Menlo Park, AAAI Press. Retrieved from https://www.aaai.org/Library/ICWSM/icwsm09contents.php

Pishchik, V., \& Spivachuk, Z. (2020). The uniqueness of values and personal traits of Generation Z students in the innovative educational space of the southern region of Russia. E3S Web of Conferences, 2104, 180358. Retrieved from https:// www.e3s-conferences.org/articles/e3sconf/abs/2020/70/contents/contents.html

Rogers E. M. (2003). Diffusion of Innovations. Free Press. Retrieved July 1, 2021. Retrieved from https://books.google.ru/ books/about/Diffusion_of_Innovations_5th_Edition.html?id=9U1K5LjUOwEC\&redir_esc=y

Rubinshtejn S. L. (2002). Bytie i soznanie. Chelovek i mir. Sankt-Peterburg: Piter. Retrieved from https://www.piter.com/ product/bytie-i-soznanie-chelovek-i-mir

Savchenko, A. B. (2012). Communicative strategies of teachers as an initiation factor of students' sense formation. Russian Psychological Journal, 9(1). 64-69. https://doi.org/10.21702/rpj.2012.1.7

Suroedova, E., Tushnova, Y., \& Belousova, E. (2020). Agriculture faculty students' meanings translation in conditions of the development of communicative competence. E3S Web of Conferences, 175, 15028. https://doi.org/10.1051/ e3sconf/202017515028

Van Dijk, T. A. (2018). Socio-cognitive discourse studies. In The Routledge Handbook of Critical Discourse Studies, Routledge, 26-43, https://doi.org/10.4324/9781315739342-3

Zorina, E. S., \& Zelenov, A. A. (2016). Psihologicheskie osnovy smyslotekhnik kak sovremennyh obrazovatel'nyh metodov [Psychological bases of sense techniques as modern educational methods]. Rossijskij psihologicheskij zhurnal, 13(1), 76-84. https://doi.org/10.21702/rpj.2016.1.6 
Ermakov, P., \& Belousova, E. (2021). The relationship between the strategies of transferring the meanings of information messages and the meaning-of-life orientations of social networks users, International Journal of Cognitive Research in Science, Engineering and Education (IJCRSEE), 9(2), 279-289. 